


Science

\title{
PHARMACEUTICO - ANALYTICAL STANDARDIZATION OF AJAMODADI CHOORNA AND ITS DRUG MODIFICATION AS AJAMODADI CHEWABLE TABLET
}

\author{
Dr. Abhilash Rajendra Dharamthok ${ }^{1}$, Dr. Mahantesh. B. Rudrapuri ${ }^{2}$, Dr. G. Vinay \\ Mohan ${ }^{3}$
}

${ }^{1}$ M.D. (Ayu.) Scholar, Department of Post Graduate Studies in Rasashastra and Bhaishajya Kalpana, Shri Shivayogeeshwar Rural Ayurvedic Medical College and Hospital, Inchal, Belgavi, Karnataka, India

${ }^{2}$ M. D. (Ayu), Professor \& Hod, Department of Rasashastra and Bhaishajya Kalpana, Shri Shivayogeeshwar Rural Ayurvedic Medical College \& Hospital, Inchal, Belgavi, Karnataka, India

${ }^{3}$ M.D. (AYU), Principal Shri Shivayogeshwar Rural Ayurvedic Medical College Inchal, Tal- Saundatti, Dist- Belagavi, Karnataka, India

\begin{abstract}
Ayurveda is ancient science. Acharya motioned chatushpada which is bhishak, dravya, rogi, upstatha. In which dravya means ayurvedic medicine Standardization of herbal formulations is important to calculate the quality of drugs, based on the concentration of their active principles. Ajamodadi Choorna is a classical formulation mentioned in Bhaisajyaratnavali with the indication Swarbheda This article highlights on pharmaceutico - analytical standardization of ajamodadi choorna and its drug modification as Ajamodadi chewable tablet standardization of Ajmodadi churna.
\end{abstract}

Keywords: Ajmodadi choorna; Ayurveda; Pharmaceutico - Analytical Standardization.

Cite This Article: Dr. Abhilash Rajendra Dharamthok, Dr. Mahantesh. B. Rudrapuri, and Dr. G. Vinay Mohan. (2019). "PHARMACEUTICO - ANALYTICAL STANDARDIZATION OF AJAMODADI CHOORNA AND ITS DRUG MODIFICATION AS AJAMODADI CHEWABLE TABLET." International Journal of Research - Granthaalayah, 7(8), 431-437. https://doi.org/10.29121/granthaalayah.v7.i8.2019.696.

\section{Introduction}

The topic of drug standardization is particularly broad and deep. There is so much to know and so many seemingly contradictory theories on the subject of herbal medicines and their relationship with human physiology and mental function. For the purpose of research work on standardization of herbal formulations and neutraceuticals, a profound knowledge of the important herbs found in India and widely used in Ayurvedic formulation is of utmost importance. 
Ayurveda is a science of life. It is mainly based on the Trisutra, Hetu, Linga and Aushadhi. ${ }^{[1]}$ Among these Aushadhi plays a major role in the treatment. In ayurveda chatuspada means bhishak, dravya, rogi, upasthata ${ }^{(2)}$ drvaya means ayurvedic medicine. Different dosage forms can be prepared by the physician according to his Yukti, considering Samyoga, Visheshakala and Samskara. There are different dosage forms explained in Ayurveda, which have been originated from Panchavidha Kashaya Kalpana (Five basic formulations).i.e swarasa,kalka,kwath,hima and fant ${ }^{(3)}$ Choorna is one of the form of kalka ${ }^{(4)}$ Choorna is powder form of drugs either in single or compound. Ajamodadi Choorna is a classical formulation mentioned in Bhaisajyaratnavali ${ }^{(5)}$ with the indication Swarbheda. The ingredients of Ajamodadi choorna are a) Ajamoda (Apium leptophyllum) b) Haridra (Curcuma longa) c)Amalaki(Emblika officinalis) d) Chitrakmoola (Plumbago zeylaniea) e) Yavakshar (Hordeum vulgare), And textual dose is 1 karsha along with honey ...Earlier period medicine was available in abundant quantity and physicians used to preparing and administer them in fresh form. Problem regarding availability of raw drug and shelf life of formulation was also not relevant. But, in today's modern era due to industrialization and deforestation availability of fresh herbs has become a major issue and conservation and standardization of the same is essential. Therefore, present study will be an attempt to standardize and to evaluate efficacy of Ajamodadi Choorna prepared by classical method as well as with modification.

\section{Materials and Method}

\section{Materials}

- Ajamodadi choorna contains 5 contains They are a) Ajamoda (Apium leptophyllum) b) Haridra (Curcuma longa) c) Amalaki (Emblika officinalis) d) Chitrakmoola (Plumbago zeylaniea) e) Yavakshar (Hordeum vulgare)

- Genuine raw material will be collected from the authenticated sources.

Table 1: Properties of contains of Ajamodadi choorna Drugs

\begin{tabular}{|c|c|c|c|c|c|c|}
\hline $\begin{array}{l}\text { SI. } \\
\text { No }\end{array}$ & Drug Name & Rasa & Guna & Virya & Vipaka & Karma \\
\hline 1 & Ajamoda $^{(6)}$ & Katu,Tikta, & $\begin{array}{l}\text { Ruksha, } \\
\text { Laghu, } \\
\text { Teekshna }\end{array}$ & Ushna & Katu & $\begin{array}{l}\text { dipaniya, vatkaphagna } \\
\text { Aruchihara } \\
\text { hrudya,balya, }\end{array}$ \\
\hline 2. & Amalaki ${ }^{(7)}$ & $\begin{array}{l}\text { Pancharasa } \\
\text { except } \\
\text { lavana }\end{array}$ & $\begin{array}{l}\text { Laghu, } \\
\text { Sara, } \\
\text { Mrudu }\end{array}$ & Shita & Madhura & $\begin{array}{l}\text { Vrushya, Rasayana, } \\
\text { Chakshusya, } \\
\text { Sarvadoshaghna }\end{array}$ \\
\hline 3 & Chitrakmoola $^{(8)}$ & Katu & $\begin{array}{l}\text { Laghu, } \\
\text { Ruksha, } \\
\text { Tikshna }\end{array}$ & Ushna & Katu & $\begin{array}{l}\text { Vatakaphahara, } \\
\text { Grahi, Deepana, } \\
\text { Pachana }\end{array}$ \\
\hline 4 & Haridra $^{(9)}$ & $\begin{array}{l}\text { Tikta, } \\
\text { Katu }\end{array}$ & Ruksha & Ushna & Katu & $\begin{array}{l}\text { Anulomana, Rasayana, } \\
\text { Hrdya, Lekhana }\end{array}$ \\
\hline 5 & Yavakshar (10) & Madhura & $\begin{array}{l}\text { Ruksha } \\
\text { Aguru } \\
\text { Mrudu }\end{array}$ & Shita & Katu & $\begin{array}{l}\text { Kaphapittahara, } \\
\text { Medhavardhaka, } \\
\text { Swaravardhaka, } \\
\text {,lekhana,Medohara }\end{array}$ \\
\hline
\end{tabular}




\section{Method}

Table 2: Properties of Ajamodadi choorna contains

\begin{tabular}{|c|c|c|c|c|c|}
\hline $\begin{array}{l}\text { Sr. } \\
\text { No }\end{array}$ & Name & Botanical name & Part used & Quantity & Chemical composition \\
\hline 1 & Ajamoda & Apium Leptophyllum & Fruits & 1 part & Ascorbic acid and Gallotannis \\
\hline 2 & Amlaki & Embilca officianalis & Fruit & 1 Part & $\begin{array}{l}\text { Golic acid, Tannic acid, } \\
\text { Glucose, Cellulose, Minerals } \\
\text { (calcium), Vitamin c }\end{array}$ \\
\hline 3 & Chitrakmoola & $\begin{array}{l}\text { Plumbagozeylanica } \\
\text { Linn }\end{array}$ & Root Bark & 1 Part & Plumbagin, Sucrose, \\
\hline 4 & Haridra & $\begin{array}{l}\text { Terminalia chebula } \\
\text { Retz }\end{array}$ & Rhizomes & 1 Part & $\begin{array}{l}\text { Ascorbic acid and } \\
\text { gallotannins. }\end{array}$ \\
\hline 5 & Yavkshar & Piper-longum Linn. & $\begin{array}{l}\text { Whole } \\
\text { plant }\end{array}$ & 1 Part & $\begin{array}{l}\text { Tannis, Amino acid, Proteins } \\
\text {, carbohydrates }\end{array}$ \\
\hline
\end{tabular}

\section{Ajamodadi Choorna Preparation}

- All the ingredients were taken in equal quantity.

- Then it was being cleaned, finely powdered separately

- After that Sieved through fine cloth (Vastragalita size 80-100)

- All the powders were mixed together to form homogeneous mixture

- Finally Store in an air tight container.

\section{Ajamodadi Chewable Tablet Preparation}

- The prepared Ajamodadi Choorna is subjected for chewable tablet preparation by wet granulation method by using non aqueous solution. Known quantity of Choorna is weighed according to the number of tablets to be compressed.

\section{Pharmaceutical Study of Ajamodadi Chewable Tablet}

Ajamodadi Churna is a poly herbal preparation \& is explained in Bhaishajya Ratnavali. This was prepared by using drugs like Ajamoda, Amalaki, Chitrak mula, Haridra \& Yavakshar. The drugs were taken in appropriate quantity as shown in the Table no .4. Churna was prepared by using Pulverizer, then filtered through the Mesh Size no 85. This fine powdered drugs were taken for chewable tablet preparation. Ajamodadi chewable Tablets were prepared in 3 sample \& were analyzed separately.

Physico chemical parameters of the individual drugs (Table no 3 ) and Ajamodadi chewable Tablets (Table no.4) were suggestive of the quality and increased shelf life.

\section{Physico-Chemical Study of 3 Samples of Ajamodadi Chewable Tablet}

\section{Organoleptic Characteristics}

Organoleptic properties are mentioned in the table no 4. The developed formulation was Buff coloured, Aromatic odour, in the samples of ACT $1 \& 3$. But in the sample ACT 3 had light yellowish in color \& Characteristics odor. 


\section{Loss on Drying}

Moisture content of sample Ajamodadi chewable Tablets 1,2,3 was found 1.04\%, 1.27\%, \& 1.04\% respectively (Table no 4). Low moisture content is desirable for higher stability of the formulation.

\section{Ash Value}

Ash value of Ajamodadi chewable Tablets sample 1,2,3 was found $2.86 \%, 2.32 \%$ \& $2.85 \%$ respectively (Table no 4). This value was found to be reasonably low, which indicates low contamination. It is criteria for identifying the purity of the drugs. Total ash is inclusive of extraneous matter such as sand, soil etc. adhering to the herbal drug.

\section{Water Soluble Ash}

Water soluble Ash of Ajamodadi chewable Tablets sample 1,2,3 was found $1.2 \%, 0.54 \% 1.2 \%$ (Table no 4) respectively. This shows normal quality of the drugs and presence of more active principle in the sample.

\section{Acid Insoluble Ash}

Acid insoluble ash of Ajamodadi chewable Tablets sample 1,2,3 was found $0.53 \%, 0.56 \%, 0.12$ $\%$ respectively (Table no 4 ). This shows indicative of very less amount of non-physiological components like silica, less adherent dirt and sand particles.

\section{The Water Soluble Extractive}

Ajamodadi chewable Tablets sample 1,2,3 were found to be $37.93 \%, 37.17 \%, 37.87 \%$ respectively.

\section{Alcohol Soluble Extractive}

Ajamodadi chewable Tablets sample 1,2,3 were found to be $43.72 \%, 42.52 \%, 43.62 \%$ respectively, indicating considerable amount of polar compounds in the sample. Extractive values are primarily useful for the determination of exhausted or adulterated drugs. The extractive value of the crude drug determines the quality as well as purity of the drug.

\section{PH Value}

$\mathrm{pH}$ of Ajamodadi chewable Tablets (sample 1,2,3) was 6, which is a weak basic. This indicates granules is gastric friendly, does not cause harm to the gastric mucosa and maintains integrity of gastric mucosa. This has shown acidic nature of formulation, due to the reason of use of ingredients.

\section{Hardness Test}

The average hardness of Ajamodadi chewable Tablets (sample $1 \& 3$ ) samples were determined by Monsanto tablet hardness tester. The hardness was found to be $2 \mathrm{~kg} / \mathrm{cm}^{2}$ (Table no 4). This indicates Ajamodadi chewable Tablets was not brittle in nature \& so it can be chewed without any difficulty.

\section{Friability Test}

It is a measure of Tablet strength. It was measured by Roche Friabilator. Friability of Ajamodadi chewable Tablets (sample $1 \& 3$ ) samples was found $0.46 \mathrm{~kg} / \mathrm{cm}^{2}$ (Table no 4). This is indicated 
acceptable form of Ajamodadi chewable Tablets \& helps to carry easily with less percentage of breakage.

\section{Weight Variation Test}

Weight variation of Ajamodadi chewable Tablets (samples of 1\& 3) was found to be $99.53 \&$ $99.50 \%$ respectively (Table no.4). This indicates each tablet contains the proper amount of drugs $\&$ by this proper fixation of therapeutic dose can be achieved.

\section{Disintegration Test}

In this Test, at the end, all the tablets of Ajamodadi chewable Tablets samples ( $1 \& 3)$ disintegrated completely in $1 \mathrm{~min}$. (Table no 4 ) without leaving any residue in the basket \& can dissolve easily in mouth.

\section{Dissolution Test}

Samples of Ajamodadi chewable Tablets (1\& 3) was found to be $91.42 \%$ \& $91.37 \%$ respectively. This is indicated optimum therapeutic effectiveness.

\section{Particle Size}

Particle size of sample Ajamodadi chewable Tablets 2 is $100-80$ mesh size. This size is suitable for product performance, stability \& appearance of the end product.

\section{Microbial Contamination}

In sample Ajamodadi chewable Tablets sample 2 was found to be absence of bacterial growth (Table no 4). This is indicated that processing was done in safety measures.

TLC (Table no 4) reveals the presence of Phyto constituents in the Ajamodadi Chewable Tablet (sample 1, 2, 3) - $\operatorname{Rf}$ values were $0.11,0.72 \& 0.11$.

Analysis of the data obtained from the analytical study suggests that the results are in within the limit.

\section{Observation and Result}

The results were assessed in following sections. Ajamodadi Chewable tablet was subjected to Physico chemical analysis. The results are tabulated in following tables.

Table 6: Physico chemical analysis of raw drugs of Ajamodadi Churna

\begin{tabular}{|c|c|c|c|c|c|c|c|c|c|}
\hline \multirow{2}{*}{$\begin{array}{l}\text { Ingredients } \\
\text { Ajamodadi } \\
\text { Churna }\end{array}$} & \multicolumn{9}{|c|}{$\begin{array}{c}\text { Test Parameters } \\
\text { Results obtained in \% }\end{array}$} \\
\hline & Color & Odor & $\begin{array}{c}\text { Loss on } \\
\text { Drying } \\
105^{0}\end{array}$ & $\begin{array}{l}\text { Total } \\
\text { Ash }\end{array}$ & $\begin{array}{c}\text { Water } \\
\text { soluble } \\
\text { ash }\end{array}$ & $\begin{array}{c}\text { Acid in } \\
\text { soluble } \\
\text { ash }\end{array}$ & $\begin{array}{c}\text { Water } \\
\text { soluble } \\
\text { extractives }\end{array}$ & $\begin{array}{c}\text { Alcohol } \\
\text { Soluble } \\
\text { Extractives }\end{array}$ & TLC \\
\hline Ajamoda & $\begin{array}{l}\text { Light } \\
\text { brown }\end{array}$ & Characteristics & $3.62 \%$ & $3.18 \%$ & $0.47 \%$ & $0.26 \%$ & $42.96 \%$ & $38.92 \%$ & 0.25 \\
\hline Aamalaki & Black & Characteristics & $1.82 \%$ & $3.11 \%$ & $0.98 \%$ & $0.71 \%$ & $39.12 \%$ & $34.43 \%$ & 0.39 \\
\hline Chitrak mool & Brown & Characteristics & $1.27 \%$ & $2.85 \%$ & $1.03 \%$ & $0.13 \%$ & $51.30 \%$ & $38.92 \%$ & 0.22 \\
\hline Haridra & Yellow & Aromatic & $2.17 \%$ & $2.35 \%$ & $0.77 \%$ & $0.62 \%$ & $44.51 \%$ & $39.91 \%$ & 0.37 \\
\hline Yavakshar & White & Characteristics & $1.43 \%$ & $1.2 \%$ & $0.97 \%$ & $0.59 \%$ & $15.74 \%$ & $17.57 \%$ & 0.76 \\
\hline
\end{tabular}


3 samples of Ajamodadi Chewable tablet was subjected to Physico chemical analysis.

The results are tabulated in following tables.

Table 4: Physico chemical analysis 3 samples of Ajamodadi Chewable tablet

\begin{tabular}{|c|c|c|c|c|}
\hline \multirow[t]{2}{*}{ Sr No } & \multirow[t]{2}{*}{ Test Parameter } & \multicolumn{2}{|c|}{ Test Results Obtained (\%) } & \\
\hline & & ACT 1 & ACT 2 & ACT 3 \\
\hline 1 & color & Buff & Light yellowish & Buff \\
\hline 2 & odor & Aromatic & Characteristics. & Aromatic \\
\hline 3 & Loss on drying at $105^{\circ} \mathrm{c}$ & $1.04 \%$ & $1.27 \%$ & $1.04 \%$ \\
\hline 4 & Ash value & $2.86 \%$ & $2.32 \%$ & $2.85 \%$ \\
\hline 5 & Water soluble ash & $1.2 \%$ & $0.54 \%$ & $1.2 \%$ \\
\hline 6 & Acid insoluble ash & $0.11 \%$ & $0.56 \%$ & $0.12 \%$ \\
\hline 7 & Water soluble extractives & $37.93 \%$ & $37.17 \%$ & $37.87 \%$ \\
\hline 8 & Alcohol Soluble Extractives & $43.72 \%$ & $42.52 \%$ & $43.62 \%$ \\
\hline 9 & pH & 6 & 6 & 6 \\
\hline 10 & Hardness Test & $2 \mathrm{~kg} / \mathrm{cm}^{2}$ & - - & $2 \mathrm{~kg} / \mathrm{cm}^{2}$ \\
\hline 11 & Friability test & 0.46 & - - & 0.46 \\
\hline 12 & Weight variation Test & 99.53 & - - & 99.50 \\
\hline 13 & Disintegration Test & $1 \mathrm{~min}$ & - & $1 \mathrm{~min}$ \\
\hline 14 & Dissolution Test & $91.42 \%$ & 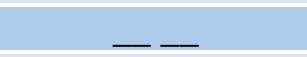 & $91.37 \%$ \\
\hline 15 & Particle size & - - & 100 - 80 mesh size & - \\
\hline 16 & Microbial contamination & & Absent & \\
\hline 17 & TLC & 0.11 & 0.72 & 0.11 \\
\hline
\end{tabular}

\section{Discussion}

"Pharmaceutico - Analytical Standardization of Ajamodadi Choorna \& Its Drug Modification As Ajamodadi Chewable Tablet" was taken in this study. Samples selected for the study shows that analytical standards were in accordance with API standards.

Physico chemical parameters of the individual drugs and Ajamodadi Chewable Tablet were suggestive of the quality and increased shelf life. Parameters results of Podwered drugs were as per the guidelines of Ayurvedic pharmacopoeia of India.

\section{Conclusion}

This study can be conclude the physicochemical standardization of herbal formulation Ajmodadi churna was carried out. The individual ingredients of the formulation were authenticated and standardized as per guidelines and Indian Herbal Pharmacopoeia.

\section{References}

[1] Dr. Brahmanada Tripathi, Charak Samhita of Maharshicharak, Vol. ${ }^{\text {st }}$ Chukhambha prakashan, Varanasi, 2011, Sutrastan, chapter 1, verse no.21, page no.09

[2] Dr. Brahmanada Tripathi, Charak Samhita of Maharshicharak, Vol. ${ }^{\text {st }}$ Chukhamabha prakashan, Varanasi, 2011, Sutrastan, chapter 09, verse no.03, page no.207 
[3] Dr. Brahmanada Tripathi, Charak Samhita of Maharshicharak, Vol. $1^{\text {st }}$ Chukhambha prakashan, Varanasi, 2011, Sutrastan, chapter 4, verse no.07, page no.70

[4] siddhinanandan mishra, bhaishajya kalpana-vighyan chokhamba subharti prakashana, Varanasi, reprint 2011.chapter no.6 page no.120

[5] Acharya Govind Das sen, Bhaisajya Ratnawali, Swararogadhikar, Chapter no.17, shlok no.6, Editor Prof. Siddhi Nandan Mishra Chaukhamba Surbharati Prakashan Varanasi Pg.No.471

[6] The Ayurvedic Pharmacopoeia of India (API), Ayush \& Family welfare dept. GOI, Vol.1 ${ }^{\text {st }}$, Reprint 2009. Page no.03

[7] The Ayurvedic Pharmacopoeia of India (API), Ayush \& Family welfare dept. GOI, Vol.1 ${ }^{\text {st }}$, Reprint 2009. Page no.07

[8] The Ayurvedic Pharmacopoeia of India (API), Ayush \& Family welfare dept. GOI, Vol.1 ${ }^{\text {st }}$, Reprint 2009. Page no.39

[9] http:/easyayurveda.com/turmeric

[10] siddhinanandan mishra, bhaishajya kalpana-vighyan chokhamba subharti prakashana, Varanasi, reprint 2011.chapter no.7, page no.218

*Corresponding author.

E-mail address: tajabhi6@gmail.com/mbrudrapuri@gmail.com/vinaymohang@ gmail.com 